\title{
Phenology, growth, and fecundity of eight subarctic tundra species in response to snowmelt manipulations
}

\author{
Sonja Wipf
}

Received: 22 January 2007 / Accepted: 3 August 2009/Published online: 21 August 2009

(C) Springer Science+Business Media B.V. 2009

\begin{abstract}
The snow cover extent is an important factor for the structure and composition of arctic and alpine tundra communities. Over the last few decades, snowmelt in many arctic and alpine regions has advanced, causing the growing season to start earlier and last longer. In a field experiment in subarctic tundra in Interior Alaska, I manipulated the timing of snowmelt and measured the response in mortality, phenology, growth, and reproduction of the eight dominant plant species. I then tested whether the phenological development of these species was controlled by snowmelt date or by temperature (in particular growing degree days, GDD). In order to expand our understanding of plant sensitivity to snowmelt timing, I explored whether the response patterns can be generalized with regard to the temporal niche of each species. Differences in the phenology between treatments were only found for the first stages of the phenological development (=phenophases). The earlier the temporal niche (i.e., the sooner after snowmelt a species develops) the more its phenology was sensitive to snowmelt. Later phenophases were
\end{abstract}

S. Wipf $(\bowtie)$

WSL Institute for Snow and Avalanche Research SLF_-Unit Ecosystem Boundaries-Team Alpine Ecosystems, Fluelastr. 11, 7260 Davos Dorf, Switzerland e-mail:wipf@slf.ch

\section{S. Wipf}

Institute of Environmental Sciences, University of Zurich, Winterthurerstr. 190, 8057 Zurich, Switzerland mostly controlled by GDD, especially in late-developing species. In no species did an earlier snowmelt and a longer growing season directly enhance plant fitness or fecundity, in spite of the changes in the timing of plant development. In conclusion, the temporal niche of a species' phenological development could be a predictor of its response to snowmelt timing. However, only the first phenophases were susceptible to changes in snowmelt, and no short-term effects on plant fitness were found.

Keywords Dwarf shrub heath · Growth · Phenology · Reproduction · Snow ecology · Winter climate change

\section{Introduction}

Under current climate change, the arctic region is experiencing among the greatest warming rates on earth (ACIA 2004; IPCC 2007). The most pronounced warming has been recorded in winter and spring (ACIA 2004; IPCC 2007). Along with the warming, significant advances in snowmelt (Dye 2002; Rikiishi et al. 2004) and an earlier onset of the growing season (Shabanov et al. 2002) have been recorded in the Arctic. Snow cover and snowmelt timing are among the most important drivers of arctic and alpine plant community composition, as seen 
from the close correlation between snowmelt patterns and vegetation distribution (Harshberger 1929; Walker et al. 1993; Sieg and Daniels 2005). However, the processes leading to these patterns, and the responses to rapid changes in snow cover due to climate change are poorly understood.

Studies that experimentally explore the effects of snow cover changes on arctic and alpine plant communities have often used snow fences, which accumulate snowdrifts in their lee and thus, increase snow depths and extend snow cover duration (e.g., Knight et al. 1979; Scott and Rouse 1995; Walsh et al. 1997; Walker et al. 1999). The responses found after such snow manipulations were often species-specific and reached from minor reactions in plant phenology, physiology, and growth (Walsh et al. 1997; Walker et al. 1999) to the total die-back of species and major changes in vegetation composition (Scott and Rouse 1995; Seastedt and Vaccaro 2001; Wahren et al. 2005). Although the duration of snow cover has been declining in many arctic and alpine regions (e.g., Dye 2002; Mote et al. 2005), only a few ecological studies have tested the ecosystem responses to earlier snowmelt. A large proportion of the published experiments have recorded the response in plant phenology (Galen and Stanton 1995; van der Wal et al. 2000; Saavedra 2002; Dunne et al. 2003; Wipf et al. 2006), but only a smaller fraction has as well studied potentially longer-lasting effects such as plant growth or reproduction (Galen and Stanton 1993; Starr et al. 2000; Saavedra 2002; Wipf et al. 2009).

There is evidence that responses to changed snowmelt timing are species-specific, however, they seem to follow certain patterns. The phenology of species with an early temporal niche (i.e., that start their phenological development early after snowmelt) did often show the strongest response (Galen and Stanton 1995; Rixen et al. 2001; Dunne et al. 2003; Wipf et al. 2006). For the fitness of early-developing species, it could be advantageous to have their phenology synchronized with snowmelt in order to exploit the whole growing season (Stinson 2004), while for later-developing species, a phenology sensitive to temperature or day length could be advantageous in order to benefit from stable, relatively warm summer temperatures or peak pollinator densities (Molau 1997). To date, no study has systematically explored whether the species-specific response patterns to snowmelt manipulations can be generalized. Considering that there is a lack in longterm experiments of reducing snow, such generalisations could be of great help to assess, whether certain species and species groups will be especially vulnerable to winter climate change. For meaningful conclusions and predictions with regard to climate change, it is also necessary to test whether changes in the phenological development will also have consequences for plant fitness and fecundity.

In this study, I explore (1) how changes in the snowmelt timing affect the mortality, phenology, growth, and reproduction of a set of eight dominating plant species in a subarctic tundra community. (2) Moreover, I test whether the phenological development of these species is controlled by snowmelt date or by growing degree days (GDD sums above $5^{\circ} \mathrm{C}$ ), and (3) whether these phenological response patterns could be generalized with regard to the temporal niche of each species. (4) In addition, I test whether changes in the phenology affects plant fitness, growth, or reproduction. Although based on a short-term approach, this study may help to understand species' patterns and sensitivities toward advanced snowmelt.

\section{Materials and methods}

Study site and species

I conducted this study from August 2002 to August 2003 in a subarctic tundra ecosystem at timberline on Murphy Dome $\left(64^{\circ} 57^{\prime} \mathrm{N}, 148^{\circ} 22^{\prime} \mathrm{W}, 850 \mathrm{~m}\right.$ a.s.1.) near Fairbanks, Interior Alaska. The location and set up are described in detail in a previous publication (Wipf et al. 2006). In short, the climate is dry and continental. The winter 2002/2003 was relatively mild, with mean temperatures of $5^{\circ}$ above and maximum snow depths $46 \%$ below normal (measured in Fairbanks AK, NOAA 2002-2003). Owing to a relatively slow snowmelt in spring 2003, snow depth was, although below average, similar or higher as in $37 \%$ of the previous 30 years when the snow manipulation started on 18 April (Daily Climatological Data, Alaska Climate Research Center, Geophysical Institute, University of Alaska Fairbanks, Fairbanks, Alaska, USA (http://climate.gi.alaska.edu)). The total precipitation was $530 \mathrm{~mm}$ over the duration of the study (measured at a nearby weather station), the mean snow depth at the site was $22 \mathrm{~cm}$ (measured 
$2 \times$ per month), and monthly mean air temperatures in January and July were $-20^{\circ} \mathrm{C}$ and $+12^{\circ} \mathrm{C}$, respectively (measured on site).

The vegetation type is a species-poor tundra dominated by deciduous and evergreen ericaceous dwarf shrubs. The species investigated in this study are the eight most frequent and abundant vascular plant species at the site, namely the evergreen shrubs Ledum palustre L. ssp. decumbens (Ait.) Hultén (frequency, recorded as $\%$ of plots occupied $=100 \%$ l abundance, recorded as $\%$ cells occupied in a $1 \mathrm{~m}^{2}$ frame divided into 25 squares $=99 \%$ ), Vaccinium vitis-idaea L. ssp. minus (Lodd.) Hultén (100/92), Empetrum nigrum L. ssp. hermaphroditum (Lange ex Hagerup) Böcher (100/74), and Cassiope tetragona (L.) D. Don (52/49), the deciduous shrubs Betula nana L. (100/48) and Vaccinium uliginosum L. (93/91), and the graminoids Carex bigelowii Torr. ex Schwein. (100/89) and Arctagrostis cf. latifolia (R. Br.) Griseb. (44/72).

Experimental design and treatments

In August 2002, I established a total of 9 blocks of 3 plots each at 3 sites in relatively flat and homogeneous terrain ( 3 sites $\times 3$ blocks per site $\times 3$ plots per block), each plot measuring $1 \mathrm{~m}^{2}$. The distance between sites was 300-400 m, between blocks within a site $15-30 \mathrm{~m}$, and between plots 3-4 $\mathrm{m}$. I tagged five random shoots or individuals of each species if present (subsequently called 'shoots'), amounting to two to five shoots per species and plot, and to a total of 989 shoots. Snow depth within plots was measured twice monthly from January to March 2003 to check for natural variability of the snow cover prior to manipulations. On 18 April 2003, I randomly assigned one of the three snowmelt treatments to each plot per block: (1) advanced snowmelt, by reducing the snow cover to approx. $10 \mathrm{~cm}$ and letting it melt naturally; (2) delayed snowmelt, by adding approx. $50 \mathrm{~cm}$ of snow and letting it melt naturally; and (3) unmanipulated control. From January to summer one temperature logger per plot measured soil surface temperatures to the nearest $0.5^{\circ} \mathrm{C}$ in $3-\mathrm{h}$ intervals. Moreover, two shaded temperature loggers in the branches of small trees (approx. $1 \mathrm{~m}$ above ground) measured the air temperatures to the nearest $0.3^{\circ} \mathrm{C}$ in hourly intervals for the duration of the experiment. Along with regular visits, the soil surface temperature measurements allowed me to detect melt-out as the first day when temperatures reached either $+5^{\circ} \mathrm{C}$ at day or $+1{ }^{\circ} \mathrm{C}$ at night. On average, plots were snow free on 28 April in controls, 20 April in plots with advanced, and 5 May in plots with delayed snowmelt. Mean snow depth before snow manipulation, winter soil temperatures, and soil moisture after snowmelt did not significantly differ between treatments (results not shown).

\section{Plant responses}

After snowmelt, I visited the plots 2-3 times weekly to record the number of living shoots, their phenological state, and the number of flower buds, flowers, and fruits of each tagged shoot. I recorded the phenological development as the date when a shoot or the first flower entered a new phenophase. Dormancy was defined as the time span between snowmelt and the first sign of plant development- this was the onset of greening in all species but E. nigrum, the reproductive buds of which broke up before greening-up. In order to record the phenological development, the following stages were monitored: vegetative stages: (1) onset of greening, i.e., first leaf entirely green in evergreens (reduction of anthocyanins), or first new leaf parts visible in deciduous species, (2) total green, i.e., all leaves green or unfolded, and (3) start of vegetative growth, i.e., start of shoot elongation; reproductive stages: (1) flower buds swelling, (2) flower open, (3) flower senescent, and (4) fruit ripe. I moreover calculated the growing degree days above $5^{\circ} \mathrm{C}$ between snowmelt and the start of each phenophase, by summing up all daily mean temperatures exceeding $5^{\circ} \mathrm{C}$ for the relevant time span.

In mid-August 2003, I recorded fecundity as the proportion of all shoots with developed fruits. In order to measure plant growth, I harvested the shoots of $C$. tetragona, E. nigrum, V. vitis-idaea, V. uliginosum, and L. palustre (harvesting the other, larger species would have been a major destructive intervention) and measured the length of the shoot increments produced in 2003 to the nearest $1 \mathrm{~mm}$. Each variable-by-species combination present in at least 12 plots was included in the analysis. Thus, the vegetative variables were analyzed for the full set of species (except "shoot growth", which was not measured in graminoids). Enough data of reproductive traits were present in four species only (see Table 1). 
Statistical analysis

The data of the marked shoots per species and plot were pooled (i.e., means for continuous and proportions for binary variables were calculated). As some species did not occur in all plots, I used linear mixedeffects models (LME with restricted maximum likelihood (REML) estimates), which deal with unbalanced designs better than least-square methods, to test for effects of snowmelt timing on mortality, timing of phenophases, growth, fecundity, and growing degree day sums. I used snowmelt date as a covariable, snowmelt treatment as a fixed factor and block nested within site as a random factor in LME models. First, I analyzed whether the date of snowmelt and the snowmelt treatment (early/control/late) affected the starting date of a phenophase of each species. By first fitting 'snowmelt date', i.e., the continuous variable that describes the experimental manipulation best, and then accounting for the factor 'snowmelt treatment', I tested whether the treatment had any residual effect beyond changing the snowmelt date. Second, I tested whether growing degree day sums were the driver of phenological development, by analyzing the degree day sums accumulated until the start of a new phenological as above (step one). If the phenological development were purely temperature driven, the growing degree day sums accumulated until the start of a phenophase would be expected to be equal, regardless of snowmelt date or treatment. Third, I tested whether snowmelt date or the timing when shoot growth and flower development started had an impact on plant growth and fecundity, respectively. For this, I analyzed the response of shoot growth increments and fecundity to the start of shoot growth and the start of flowering, respectively.

At last, I analyzed whether the synchrony of a species' phenology with snowmelt decreased with a later temporal niche. As a measure of the temporal niche, I regarded the date when control shoots entered the respective phenophase (mean over all control plots). As a measure of a species' synchrony with snowmelt, I recorded for each species and

Table 1 Compilation of the controls on phenology of eight subarctic tundra species in the order when the respective phenophase was attained by each species (left to right)

Rank order when a phenophase is attained

\begin{tabular}{|c|c|c|c|c|c|c|c|c|}
\hline Phenophase & 1 & 2 & 3 & 4 & 5 & 6 & 7 & 8 \\
\hline Duration of dormancy & Empetrum & Cassiope & V. v. $-i$. & Betula & V. ulig. & Ledum & Carex & Arctagr. \\
\hline Onset of greening & Cassiope & V. v. $-i$. & Betula & V. ulig. & Empetrum & Carex & Ledum & Arctagr. \\
\hline Total green & Cassiope & V. v. $-i$. & Empetrum & Betula & Ledum & V. ulig. & Arctagr. & Carex \\
\hline Start of growth & Empetrum & Cassiope & V. ulig. & V. v. $-i$. & Ledum & Betula & & \\
\hline Bud break & Empetrum & Carex & V. ulig. & Ledum & & & & \\
\hline Flowering & Empetrum & Carex & V. ulig. & Ledum & & & & \\
\hline
\end{tabular}

Gray cells: controlled by snowmelt, i.e., timing of phenophase of the respective species is influenced by snowmelt timing; black cells: controlled by temperature, i.e., phenophase of the respective species is reached after an equal sum of growing temperatures in all snowmelt treatments; white cells: none of the above. See results and appendix Tables 2 and 3 for detailed results

Arctagr. = Arctagrostis, V. v.-i. = Vaccinium vitis-idaea, V. ulig = Vaccinium uliginosum; see methods for full species names of the other species 
phenophase the strength of its relationship with the date of snowmelt (i.e., standardized correlation coefficients). I tested with linear regression, whether the synchrony with snowmelt of a phenophase depended on the temporal niche across all species. Residuals were checked for normality, and variables were transformed if necessary (ln transformation for shoot increments, arcsin-root transformation for proportion data, i.e., mortality and fecundity). Analyses were performed using the nlme package in $\mathrm{R}$ 2.7.1 ( $\mathrm{R}$ Development Core Team 2008).

\section{Results}

Mortality

A total of $96 \%$ of 989 shoots survived the experiment. The mortality ranged from $0 \%$ in $C$. bigelowii and Arctagrostis sp. to $10.3 \%$ in V. vitis-idaea. Although low in total, mortality was by far highest in early-melting plots $(64,29$, and $7 \%$ of dead shoots over all species occurred in early, ambient, and latemelting plots, respectively). On the species level, only $V$. vitis-idaea mortality was significantly affected by snowmelt timing, while the treatment had no further impact (Fig. 1, Table 2 in Appendix).

Phenology

The earlier the snow melted, the longer shoots generally remained dormant (Fig. 1). Earlier snowmelt significantly increased the length of dormancy in all species except $C$. tetragona (Table 2 in Appendix). GDD accumulated during dormancy was negatively correlated with snowmelt date in all species except $B$. nana and $C$. bigelowii, suggesting that the break of dormancy was not dependent of a decisive amount of GDD in most species (Table 2 in Appendix). The start of the first vegetative phenophase, i.e., onset of greening, was advanced by earlier snowmelt date in B. nana, C. tetragona, E. nigrum, and $V$. vitis-idaea, but tended to be delayed in Arctagrostis (Fig. 2, Table 2 in Appendix). Upon onset of greening, the GDD were correlated with snowmelt date in C. tetragona, E. nigrum, and $L$. palustre (only marginally significantly), and $V$. uliginosum, thus GDD did not induce greening-up in these species (Table 2 in Appendix). The

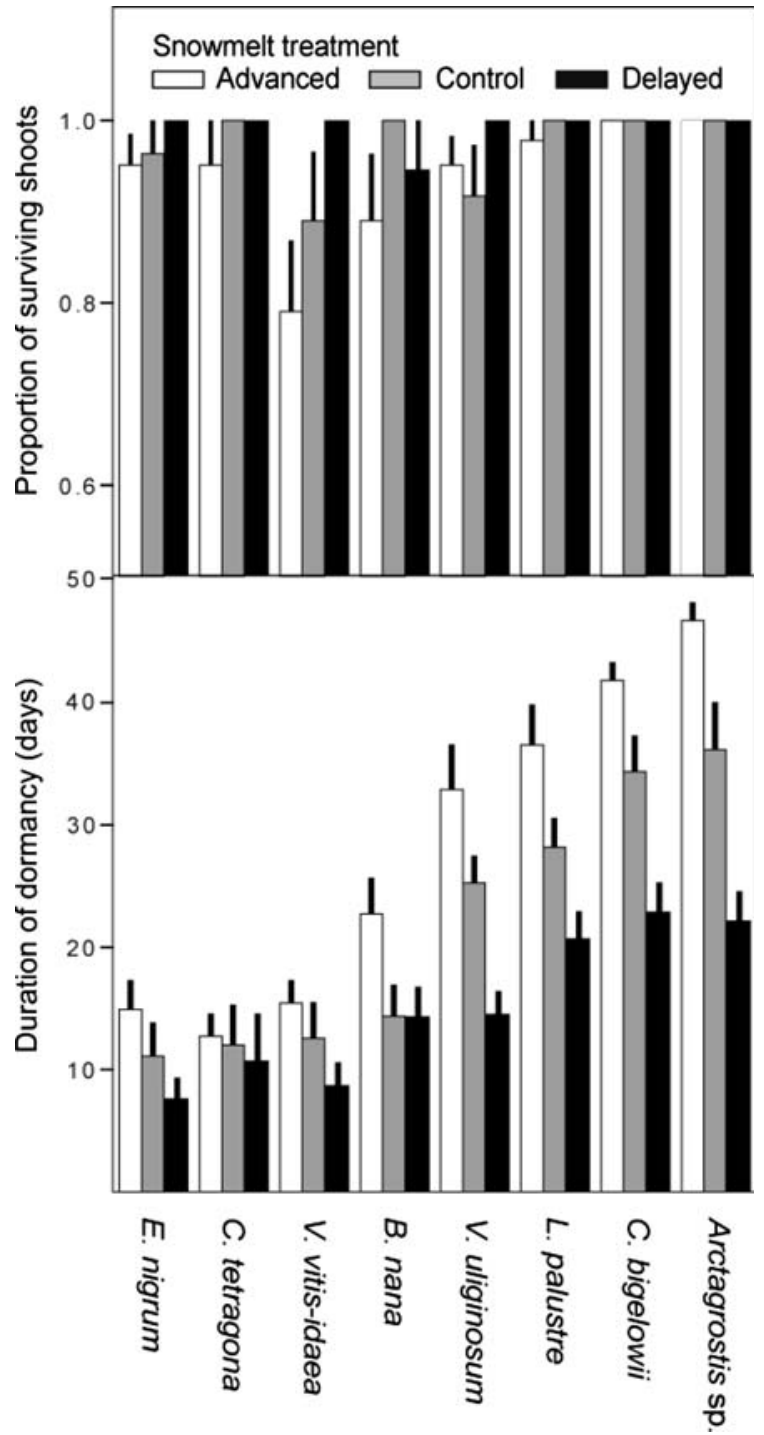

Fig. 1 The proportion of shoots of eight frequent tundra species surviving the snowmelt experiment (above), and the duration of their dormancy (i.e., snowmelt date until onset of greening or break of flower buds, whichever occurred earlier; below) in response to experimental changes in snowmelt timing. Mean snowmelt date was 28 April in controls, 20 April in plots with advanced, and 5 May in plots with delayed snowmelt

difference in phenology between plots had vanished once all the leaves became green and unfolded; $V$. uliginosum shoots even had their leaves unfolded later after advanced snowmelt (Fig. 2, Table 2 in Appendix). The lack of relationship between snowmelt and GDD in all other species suggests that the process of greening was mainly temperature driven 


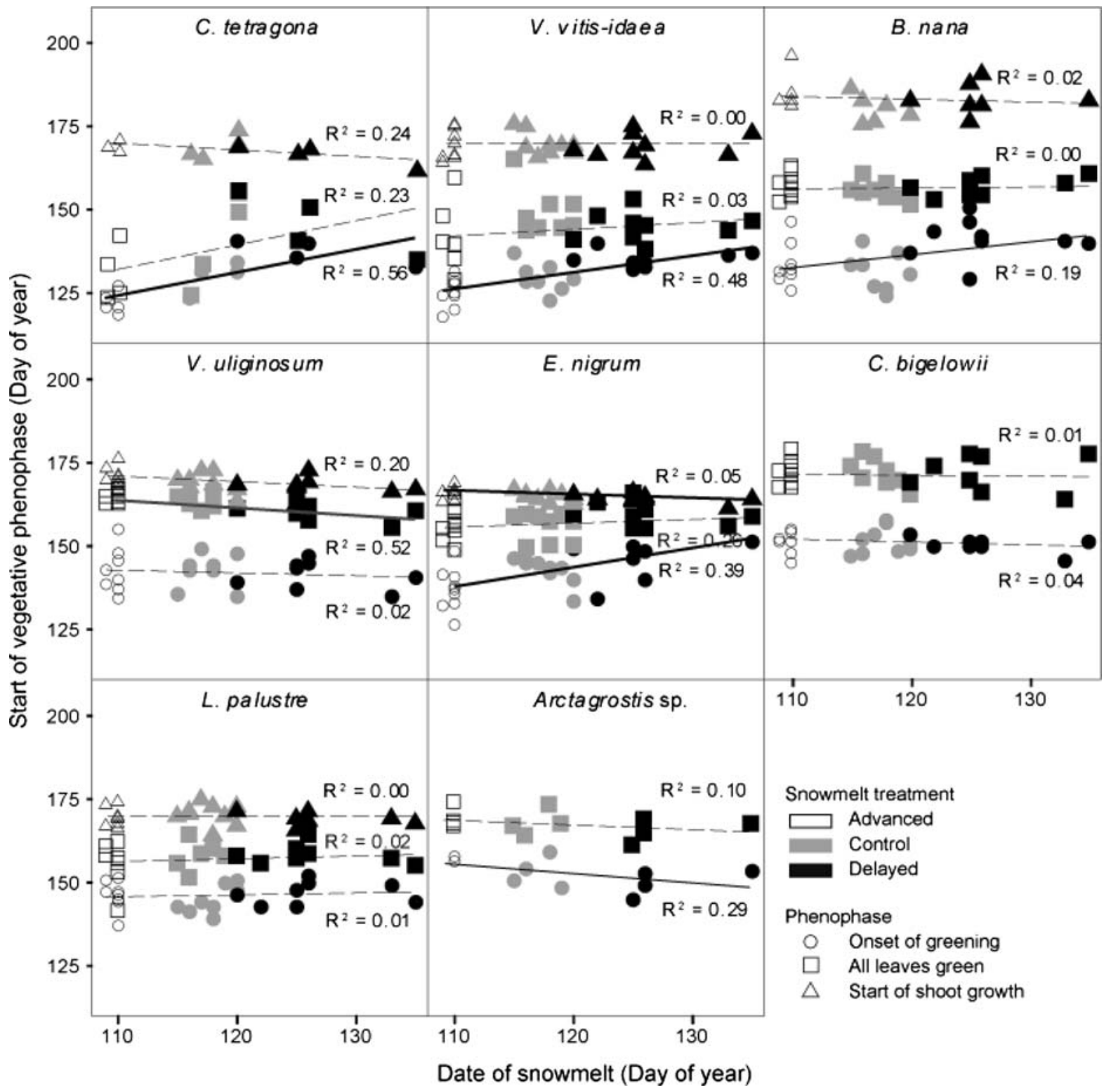

Fig. 2 The vegetative phenology of eight frequent tundra species after manipulations of snowmelt timing. Symbols mark the mean date when tagged shoots in a plot reached a new phenophase. Bold solid lines significant at the $P<0.05$ level,

(Table 2 in Appendix). Vegetative shoot growth started earlier after delayed snowmelt date in $E$. nigrum (Fig. 2, Table 2 in Appendix), but was temperature dependent in all other species except $V$. uliginosum (no snowmelt effect on GDD, Table 2 in Appendix).

The timing of the first reproductive phenophases of E. nigrum, i.e., break of flower buds and flowering, thin solid lines marginally significant at the $P<0.1$ level, dashed lines not significant (see Table 2 in Appendix for analyses and full species names). Day of year $121=1$ May, $152=1$ June, $182=1$ July

were earlier after advanced snowmelt (Fig. 3, Table 3 in Appendix). The lack of a relationship between snowmelt timing and GDD suggests that flowering in C. bigelowii, L. palustre, and V. uliginosum was controlled by temperature, and that a sum of 133 , 238 , and $134^{\circ} \mathrm{C}$ above a threshold of $5^{\circ} \mathrm{C}$ had to be accumulated before these species started to flower. Neither the duration of flowering nor the date when 
Fig. 3 The reproductive phenology of four frequent tundra species after manipulations of snowmelt timing. Symbols mark the mean date when tagged shoots in a plot reached a new phenophase. Bold solid lines significant at the $P<0.05$ level, thin solid lines marginally significant at the $P<0.1$ level, dashed lines not significant (see Table 3 in Appendix for analyses and full species names). Day of year $121=1$ May, $152=1$ June, $182=1$ July

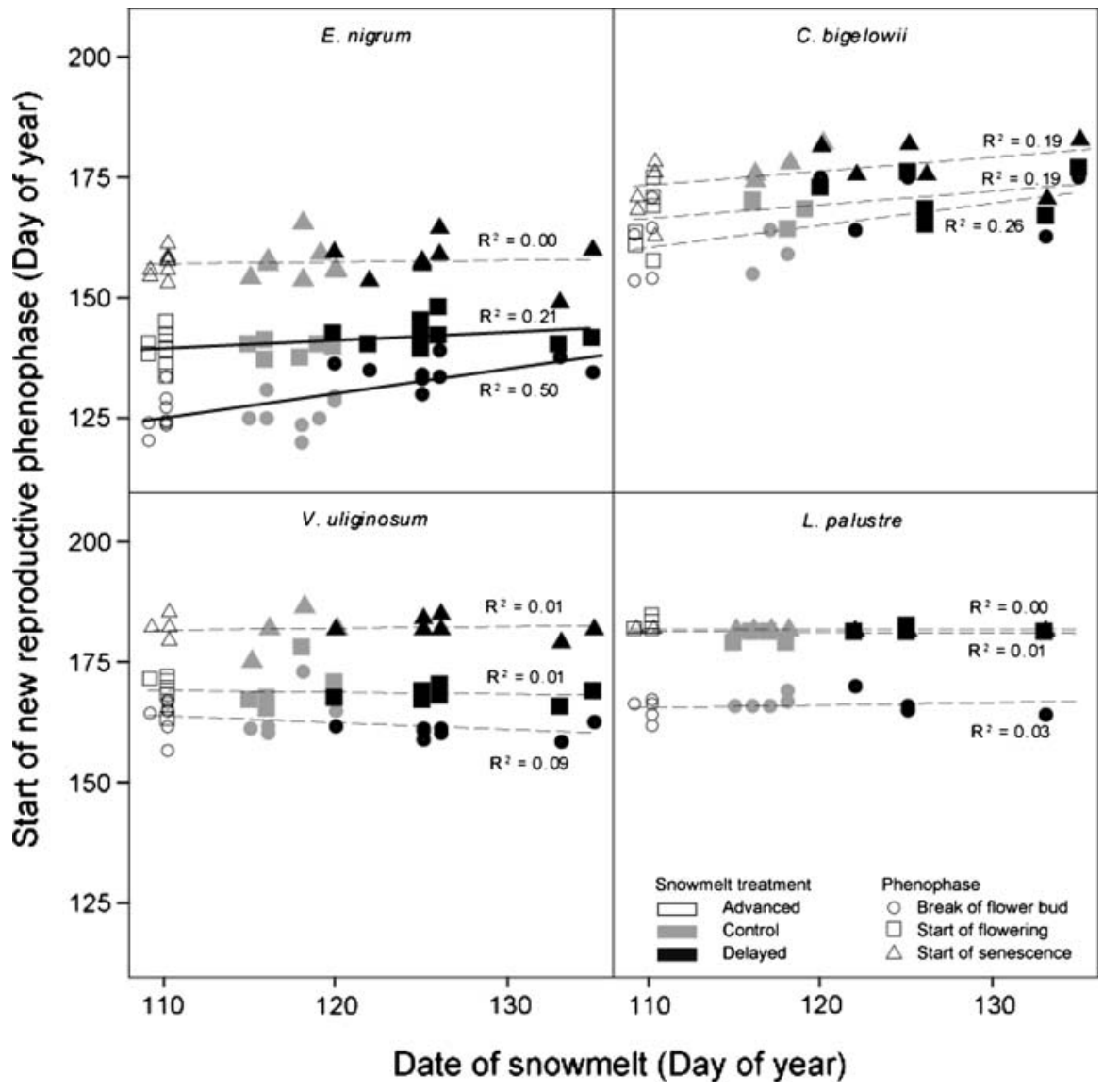

Fig. 4 The synchrony of a species' phenology with snowmelt in relation to the temporal niche of a species (i.e., date of the respective phenophase in control plots, on X-axis). Synchrony with snowmelt was expressed as the standardized correlation coefficients between snowmelt date and the phenophases a onset of greening of leaves, and $\mathbf{b}$ all leaves green. Day of year $121=1$ May, $152=1$ June

(a)

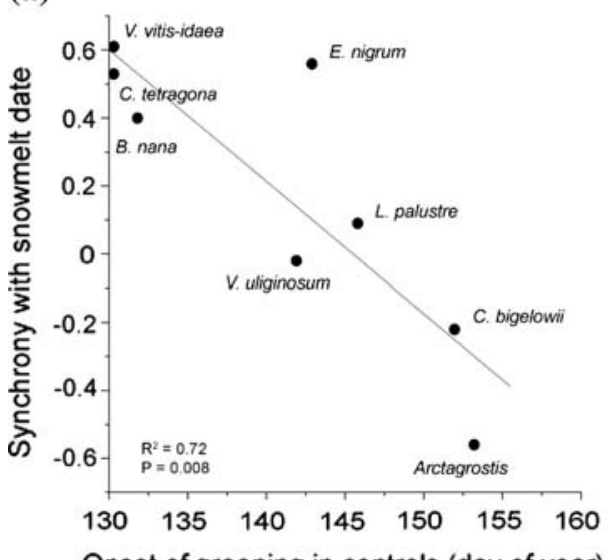

Onset of greening in controls (day of year) (b)

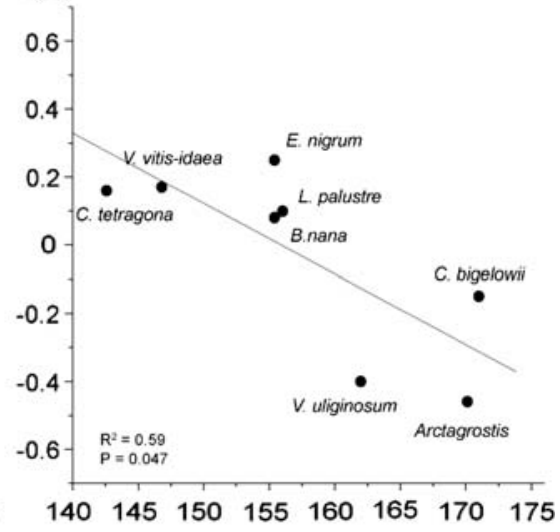

All leaves green in controls (day of year) later reproductive stages were reached (flower senescence, ripening of fruits) was influenced by snowmelt timing (results not shown).

The earlier the temporal niche of a species, the more was its initial phenological development influenced by snowmelt date (Table 1, Fig. 4). The relationship between the degree of synchrony with snowmelt and the temporal niche of the development was significantly negative for the first vegetative phenophases (onset of greening: $F_{1,6}=15.0$, 
Fig. 5 The relationship between the date when shoot growth started and the length of the shoot increment produced in the same year in a snowmelt experiment in subarctic tundra. Day of year $121=1$ May, $152=1$ June, $182=1$ July

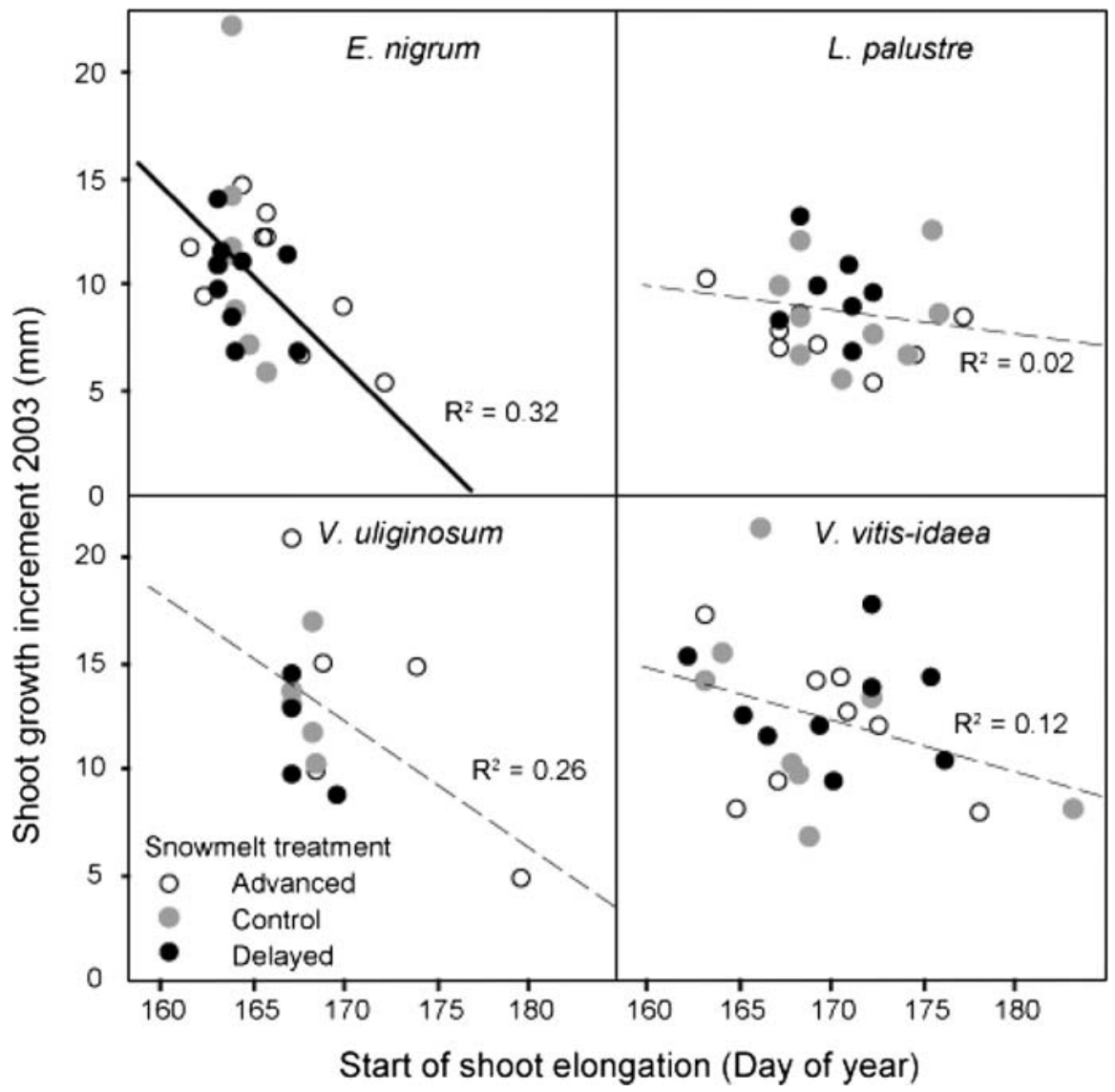

$P=0.008$; total greening: $F_{1,6}=6.2, P=0.047$;

Fig. 4). There was no significant relationship between a species' sensitivity to snowmelt and its temporal niche for the start of vegetative growth and reproductive phenophases. However, these stages were only analyzed for 6 and 4 species, respectively (see Table 1).

Growth and reproduction

The shoot growth increments produced by L. palustre in the summer following the snowmelt manipulation were longer after later snowmelt, but those of the other species did not respond to snowmelt timing. While shoot increments of E. nigrum were increased after an earlier start of vegetative growth, and thus, with higher accumulation of GDD during growth (Table 2 in Appendix, Fig. 5), V. vitis-idaea shoots tended to respond the opposite way (negative effect of GDD).
The fecundity (i.e., the proportion of shoots bearing fruits) of $C$. bigelowii and E. nigrum was significantly increased by later snowmelt (Table 3 in Appendix), and in E. nigrum also by later flowering; fecundity was increased by 61 and 199\%, respectively, in late-melting plots compared to controls.

\section{Discussion}

Environmental controls on phenology

In order to assess a species' vulnerability to phenological changes it is of special importance to know the environmental factors that control its development. This snow manipulation experiment revealed that relatively small changes in snowmelt timing could affect the mortality, phenology, and reproduction of the most frequent plant species of an Alaskan subarctic tundra community. The phenological response to snowmelt manipulations showed two 
patterns. Firstly, only early stages in the phenological development responded to snowmelt timing, whereas later phenophases were controlled by temperature rather than snowmelt in most species. Secondly, the inherent temporal niche of a species, i.e., whether its development occurs early or late in the growing season, partly controlled whether a species' phenology was responsive to snowmelt manipulations.

Although snowmelt timing was an important factor for alpine and arctic plant development in many studies (e.g., Galen and Stanton 1995; Dunne et al. 2003; Wipf et al. 2006; Borner et al. 2008), it is only one of several possible drivers of plant phenology. Numerous studies concluded that temperature, most often expressed as cumulative temperature sums (GDD or thawing degree days, TDD), was the main driver of phenology in alpine and arctic plants, and that plants have to accumulate a certain amount of growing temperatures before reaching the next phenophase (e.g., Kudo and Suzuki 1999; Molau et al. 2005; Huelber et al. 2006). Other important factors are day length (e.g., Heide 2001; Keller and Körner 2003) and soil moisture (Walker et al. 1995). It is unlikely that day length played a role in this study, as at snowmelt days were already longer than considered critical for arctic and alpine plant development (15 h, Heide 2001; 16 h, Keller and Körner 2003). Plots of the three treatments might have experienced different soil moisture regimes just after snowmelt, however, differences in soil moisture between treatments had vanished two weeks after snowmelt (S. Wipf, unpublished data), when several of the species had not reached the first phenophase yet.

Generalizations about the environmental controls on phenology of alpine and arctic plants are difficult, as they differ between species within the same habitat (Walker et al. 1995; Keller and Körner 2003), between habitats in the same species (Walker et al. 1995; Saavedra 2002), or between phenophases in the same species (Wielgolaski 2003). This experiment gives evidence that the controls on phenology are partly linked to the temporal niche of a species: the timing of the first phenophases and the phenology of early-developing species were predominantly controlled by snowmelt, while those of the latter stages and later-developing species were mostly controlled by GDD. This 1 year experiment is not able to prove that these patterns hold true for other years or different species, however, a relationship between snowmelt, phenology, and temporal niche has also been found (although not always explicitly stated) in several other snow manipulation studies (Galen and Stanton 1995; Rixen et al. 2001; Dunne et al. 2003; Inouye 2008), showing that it is at least a widespread phenomenon in alpine and arctic ecosystems.

Effects of snowmelt and phenology on reproduction and growth

Fecundity was enhanced by later snowmelt in $C$. bigelowii and E. nigrum, the two earliest flowering of the four species that reproduced in sufficient numbers to be included in this study. In field experiments, reproductive fitness of subarctic and arctic species was often positively related to temperature (e.g., Arft et al. 1999; Dormann and Woodin 2002; Hollister et al. 2005). After an earlier snowmelt, the remaining growing season is cooler on average, as the snow free season starts further away from peak summer temperatures (Kudo and Suzuki 1999; Walker et al. 1999). Also, the risk of spring frosts is increased, which are of special concern for early-flowering species (Molau 1997; Inouye 2000; Inouye 2008). Thus, in early-flowering species, the potentially positive effect of a longer period for flowering and seed production after earlier snowmelt seems to be outweighed by lower mean temperatures and higher frost risk during key phenophases. Late-flowering species, on the other hand, are at risk of losing their seed crop when winter starts early (Molau 1993). Thus, the effect of snowmelt timing and flowering phenology on reproduction is presumably heavily influenced by stochastic events such as frosts or onset of winter. While this 1 year study is not capable of capturing such inter-annual fluctuations, the large variation in plant reproduction in multi-year snow manipulation (Galen and Stanton 1993; Saavedra 2000; Aerts et al. 2004; Stinson 2004) or landscape scale studies (Molau 1993; Kudo and Suzuki 2002; Inouye 2008) illustrates the importance of environmental stochasticity for alpine and arctic plant development.

Reproduction is predominantly clonal in many tundra plants (Bliss 1971), thus when testing climate change scenarios, mortality rates and vegetative growth could be more important indicators 
for future vegetation turnover than phenology and reproduction. In this study, mortality was low in total, but highest in early-melting plots, indicating that growing conditions were most harsh after advanced snowmelt (see also Wipf et al. 2006). The species with earliest break of dormancy, $V$. vitis-idaea, showed the highest mortality. Shoot growth did not directly respond to snowmelt timing, even if the start of the vegetative growth, and thus, the time available for growth, had been controlled by snowmelt date. This is in line with the minor short-term effects of changed snowmelt timing on arctic and alpine plant growth found in other studies (Walker et al. 1999; Starr et al. 2000; van der Wal et al. 2000; Wipf et al. 2006).

Only one plant species in our study, the earlydeveloping E. nigrum, showed a relationship between earlier start of shoot growth and longer shoot increments. Hence, most tundra plants were able to compensate for changes in their phenological development, for instance with a plastic response in their growth rates. Still, changes in phenology can have indirect consequences for plant fitness, for instance by modifying the interaction between plants and their herbivores (van der Wal et al. 2000; Roy et al. 2004), pollinators (Kudo 1993; Molau 1997), or pathogens (Sturges 1989; Roy et al. 2004). Thus, phenology is an important tool to understand direct or indirect impacts of environmental change on plant fitness. Further studies or re-analyses of existing data sets are needed to verify the patterns found in the controls of phenological development and test whether the temporal niche of a species gives indications about its fate and performance in longterm experiments.

Acknowledgements I am grateful to C. Rixen for help throughout this study, C.P.H. Mulder for temperature data, P. Bebi, V. Stoeckli, and anonymous reviewers for helpful comments on an earlier version of the manuscript, the Swiss Academy of Natural Sciences for travel grants, and the Institute of Arctic Biology, University of Alaska, Fairbanks for allowing me to use its facilities. This study was financed by the WSL Institute for Snow and Avalanche Research SLF.

\section{Appendix}

See Tables 2 and 3.

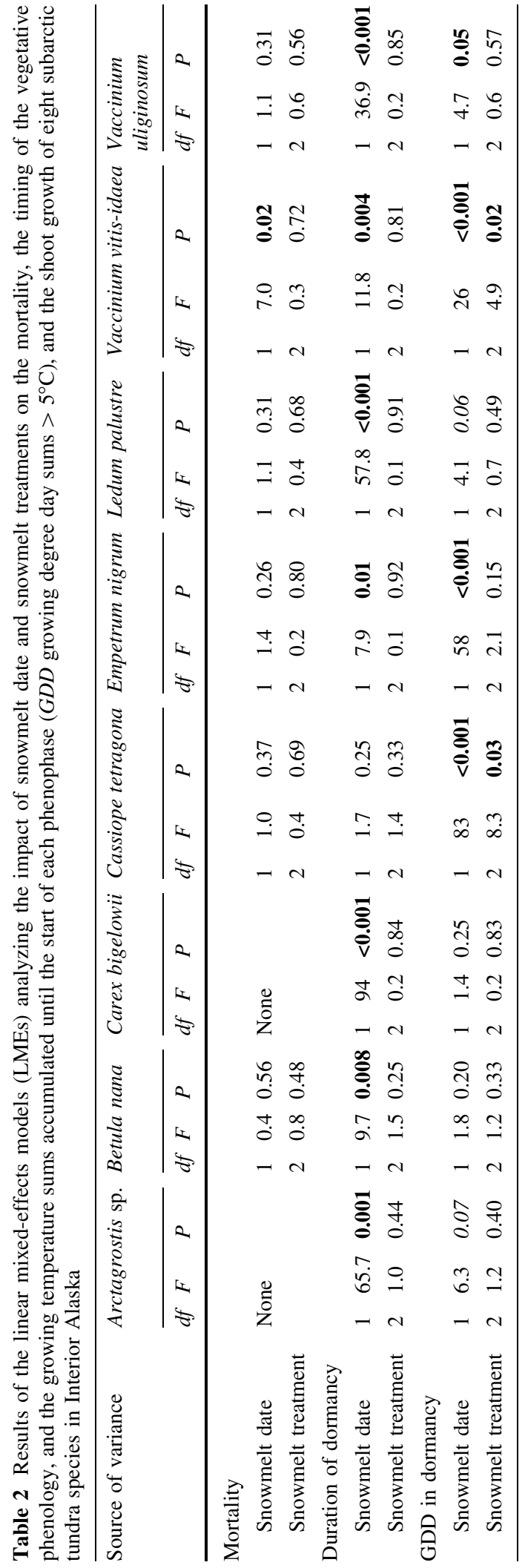




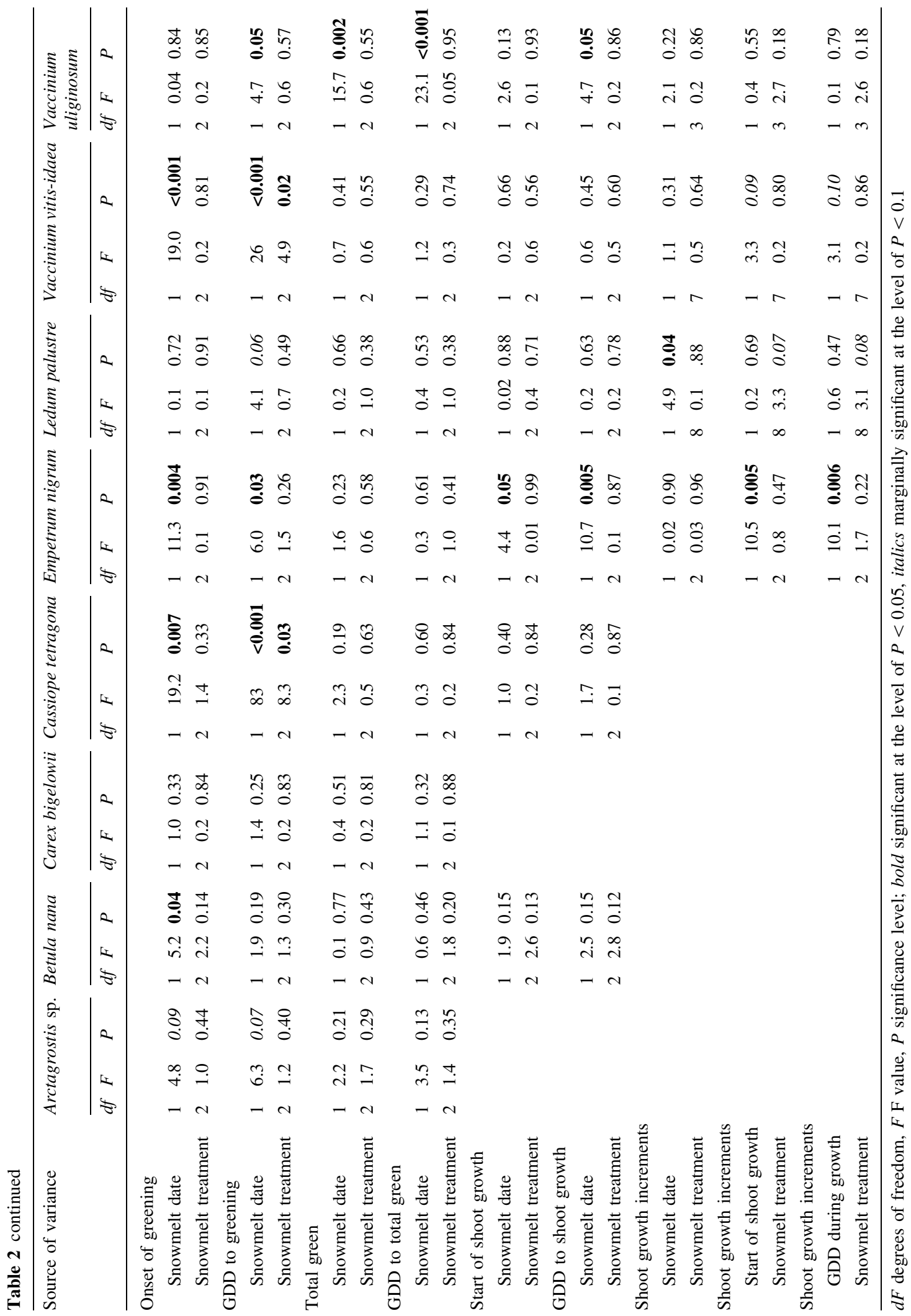


Table 3 Results of the linear mixed-effects models (LMEs) analyzing the impact of snowmelt date and snowmelt treatments on the timing of the reproductive phenology, growing temperature sums accumulated until the start of the respective phenophase $\left(G D D\right.$ growing degree days sums $\left.>5^{\circ} \mathrm{C}\right)$, and the fecundity of four subarctic tundra species in Interior Alaska

\begin{tabular}{|c|c|c|c|c|c|c|c|c|c|c|c|c|}
\hline \multirow[t]{2}{*}{ Source of variance } & \multicolumn{3}{|c|}{ Carex bigelowii } & \multicolumn{3}{|c|}{ Empetrum nigrum } & \multicolumn{3}{|c|}{ Ledum palustre } & \multicolumn{3}{|c|}{ Vaccinium uliginosum } \\
\hline & $d f$ & $F$ & $P$ & $d f$ & $F$ & $P$ & $d f$ & $F$ & $P$ & $d f$ & $F$ & $P$ \\
\hline \multicolumn{13}{|l|}{ Break of flower buds } \\
\hline Snowmelt date & 1 & 4.7 & 0.1 & 1 & 23.0 & $<0.001$ & 1 & 0.3 & 0.64 & 1 & 1.6 & 0.24 \\
\hline Snowmelt treatment & 2 & 0.8 & 0.51 & 2 & 2.1 & 0.16 & 2 & 1.4 & 0.32 & 2 & 1.5 & 0.28 \\
\hline \multicolumn{13}{|c|}{ GDD until break of flower buds } \\
\hline Snowmelt date & 1 & 4.1 & 0.11 & 1 & 64.7 & $<0.001$ & 1 & 0.1 & 0.76 & 1 & 2.9 & 0.12 \\
\hline Snowmelt treatment & 2 & 0.8 & 0.51 & 2 & 4.5 & $\mathbf{0 . 0 3}$ & 2 & 1.2 & 0.37 & 2 & 1.6 & 0.25 \\
\hline \multicolumn{13}{|l|}{ Start of flowering } \\
\hline Snowmelt date & 1 & 1.8 & 0.23 & 1 & 5.3 & 0.04 & 1 & 0.1 & 0.78 & 1 & 0.1 & 0.78 \\
\hline Snowmelt treatment & 2 & 0.2 & 0.85 & 2 & 0.3 & 0.76 & 2 & 3.9 & 0.11 & 2 & 0.9 & 0.43 \\
\hline \multicolumn{13}{|c|}{ GDD until start of flowering } \\
\hline Snowmelt date & 1 & 1.0 & 0.35 & 1 & 27.0 & $<0.001$ & 1 & 1.2 & 0.34 & 1 & 0.5 & 0.48 \\
\hline Snowmelt treatment & 2 & .2 & 0.79 & 2 & 1.8 & 0.21 & 2 & 4.7 & 0.09 & 2 & 1.0 & 0.40 \\
\hline \multicolumn{13}{|c|}{ Fecundity ( $\mathrm{p}$ shoots with fruits) } \\
\hline Snowmelt date & 1 & 9.2 & 0.004 & 1 & 6.0 & $\mathbf{0 . 0 3}$ & 1 & 0.2 & 0.64 & 1 & 1.7 & 0.22 \\
\hline Snowmelt treatment & 2 & 0.7 & 0.52 & 2 & 3.0 & 0.08 & 2 & 0.1 & 0.88 & 2 & 0.3 & 0.74 \\
\hline \multicolumn{13}{|c|}{ Fecundity (p shoots with fruits) } \\
\hline Start of flowering & 1 & 0.02 & 0.89 & 1 & 9.1 & 0.01 & 1 & 0.4 & 0.58 & 1 & 1.5 & 0.25 \\
\hline Snowmelt treatment & 2 & 1.2 & 0.37 & 6 & 1.3 & 0.32 & 1 & 0.5 & 0.66 & 5 & 1.4 & 0.30 \\
\hline
\end{tabular}

$d F$ degrees of freedom, $F$ F value, $P$ significance level; bold significant at the level of $P<0.05$, italics marginally significant at the level of $P<0.1$

\section{References}

ACIA (2004) Impacts of a warming Arctic: Arctic climate impact assessment. Cambridge University Press, Cambridge

Aerts R, Cornelissen JHC, Dorrepaal E, van Logtestijn RSP, Callaghan TV (2004) Effects of experimentally imposed climate scenarios on flowering phenology and flower production of subarctic bog species. Global Change Biol 10:1599-1609

Arft AM, Walker MD, Gurevitch J, Alatalo JM, Bret-Harte MS, Dale M, Diemer M, Gugerli F, Henry GHR, Jones MH, Hollister RD, Jonsdottir IS, Laine K, Levesque E, Marion GM, Molau U, Molgaard P, Nordenhall U, Raszhivin V, Robinson CH, Starr G, Stenstrom A, Stenstrom M, Totland O, Turner PL, Walker LJ, Webber PJ, Welker JM, Wookey PA (1999) Responses of tundra plants to experimental warming: meta-analysis of the international tundra experiment. Ecol Monogr 69:491-511

Bliss LC (1971) Arctic and alpine plant life cycles. Annu Rev Ecol Syst 2:405-438

Borner A, Kielland K, Walker M (2008) Effects of simulated climate change on plant phenology and nitrogen mineralization in Alaskan arctic tundra. Arct Antarct Alp Res 40:27-38
Dormann CF, Woodin SJ (2002) Climate change in the Arctic: using plant functional types in a meta-analysis of field experiments. Funct Ecol 16:4-17

Dunne JA, Harte J, Taylor KJ (2003) Subalpine meadow flowering phenology responses to climate change: integrating experimental and gradient methods. Ecol Monogr 73:69-86

Dye DG (2002) Variability and trends in the annual snowcover cycle in Northern Hemisphere land areas, 19722000. Hydrol Process 16:3065-3077

Galen C, Stanton ML (1993) Short-term responses of alpine buttercups to experimental manipulations of growingseason length. Ecology 74:1052-1058

Galen C, Stanton ML (1995) Responses of snowbed plantspecies to changes in growing-season length. Ecology 76:1546-1557

Harshberger JW (1929) Preliminary notes on American snow patches and their plants. Ecology 10:275-281

Heide OM (2001) Photoperiodic control of dormancy in Sedum telephium and some other herbaceous perennial plants. Physiol Plant 113:332-337

Hollister RD, Webber PJ, Bay C (2005) Plant response to temperature in Northern Alaska: implications for predicting vegetation change. Ecology 86:1562-1570 
Huelber K, Gottfried M, Pauli H, Reiter K, Winkler M, Grabherr G (2006) Phenological responses of snowbed species to snow removal dates in the Central Alps: implications for climate warming. Arct Antarct Alp Res 38:99-103

Inouye DW (2000) The ecological and evolutionary significance of frost in the context of climate change. Ecol Lett 3:457-463

Inouye DW (2008) Effects of climate change on phenology, frost damage, and floral abundance of montane wildflowers. Ecology 89:353-362

IPCC (ed) (2007) Climate change 2007: the physical science basis. Contribution of working group I to the fourth assessment report of the Intergovernmental Panel on Climate Change. Cambridge University Press, Cambridge, New York

Keller F, Körner C (2003) The role of photoperiodism in alpine plant development. Arct Antarct Alp Res 35:361-368

Knight DH, Weaver SW, Starr CR, Romme WH (1979) Differential response of subalpine meadow vegetation to snow augmentation. J Range Manage 32:356-359

Kudo G (1993) Relationship between flowering time and fruitset of the entomophilous alpine shrub, Rhododendron aureum (Ericaceae), inhabiting snow patches. Am J Bot 80:1300-1304

Kudo G, Suzuki S (1999) Flowering phenology of alpine plant communities along a gradient of snowmelt timing. Polar Biosci 12:100-113

Kudo G, Suzuki S (2002) Relationships between flowering phenology and fruit-set of dwarf shrubs in alpine Fellfields in northern Japan: a comparison with a subarctic heathland in northern Sweden. Arct Antarct Alp Res 34:185-190

Molau U (1993) Relationships between flowering phenology and life-history strategies in tundra plants. Arct Alp Res 25:391-402

Molau U (1997) Phenology and reproductive success in arctic plants: susceptibility to climate change. In: Oechel WC, Callaghan T, Gilmanov TG, Holten JI, Maxwell B, Molau U, Sveinbjornsson B (eds) Global change and arctic terrestrial ecosystems. Springer, New York, pp 153-170

Molau U, Nordenhall U, Eriksen B (2005) Onset of flowering and climate variability in an alpine landscape: a 10-year study from Swedish Lapland. Am J Bot 92:422-431

Mote PW, Hamlet AF, Clark MP, Lettenmaier DP (2005) Declining mountain snowpack in western North America. Bull Amer Meteorol Soc 86:39-49

NOAA (2002-2003) Local climatological data for Fairbanks, AK. National Climatic Data Center, Asheville

R Development Core Team (2008) R: A language and environment for statistical computing. R Foundation for Statistical Computing, Vienna, Austria

Rikiishi K, Hashiya E, Imai M (2004) Linear trends of the length of snow-cover season in the Northern Hemisphere as observed by the satellites in the period 1972-2000. Ann Glaciol 38:229-237

Rixen C, Stoeckli V, Huovinen C, Huovinen K (2001) The phenology of four subalpine herbs in relation to snow cover characteristics. In: Proceedings of the sixth IAHS Symposium 2001. Soil-Vegetation-Atmosphere Transfer
Schemes and Large Scale Hydrological Models. IAHS Publications, Maastricht, pp 359-362

Roy BA, Gusewell S, Harte J (2004) Response of plant pathogens and herbivores to a warming experiment. Ecology 85:2570-2581

Saavedra F (2000) Potential impact of climate change on the phenology and reproduction of Delphinium nuttallianum (Ranunculaceae). University of Maryland, Baltimore, p 185

Saavedra F (2002) Testing climate change predictions with the subalpine species Delphinium nuttallianum. In: Schneider SH, Root TL (eds) Wildlife responses to climate change. Island Press, Washington, pp 201-249

Scott PA, Rouse WR (1995) Impacts of increased winter snow cover on upland tundra vegetation-A case example. Clim Res 5:25-30

Seastedt TR, Vaccaro L (2001) Plant species richness, productivity, and nitrogen and phosphorus limitations across a snowpack gradient in alpine tundra, Colorado, USA. Arct Antarct Alp Res 33:100-106

Shabanov NV, Zhou LM, Knyazikhin Y, Myneni RB, Tucker CJ (2002) Analysis of interannual changes in northern vegetation activity observed in AVHRR data from 1981 to 1994. IEEE Trans Geosci Remote Sens 40:115-130

Sieg B, Daniels FJA (2005) Altitudinal zonation of vegetation in continental West Greenland with special reference to snowbeds. Phytocoenologia 35:887-908

Starr G, Oberbauer SF, Pop EW (2000) Effects of lengthened growing season and soil warming on the phenology and physiology of Polygonum bistorta. Global Change Biol 6:357-369

Stinson KA (2004) Natural selection favors rapid reproductive phenology in Potentilla pulcherrima (Rosaceae) at opposite ends of a subalpine snowmelt gradient. Am J Bot 91:531-539

Sturges DL (1989) Response of mountain big sagebrush to induced snow accumulation. J Appl Ecology 26:10351041

van der Wal R, Madan N, van Lieshout S, Dormann C, Langvatn R, Albon SD (2000) Trading forage quality for quantity? Plant phenology and patch choice by Svalbard reindeer. Oecologia 123:108-115

Wahren C-HA, Walker MD, Bret-Harte MS (2005) Vegetation responses in Alaskan arctic tundra after 8 years of a summer warming and winter snow manipulation experiment. Global Change Biol 11:537-552

Walker DA, Halfpenny JC, Walker MD, Wessman CA (1993) Long-term studies of snow-vegetation interactions. Bioscience 43:287-301

Walker MD, Ingersoll RC, Webber PJ (1995) Effects of interannual climate variation on phenology and growth of two alpine forbs. Ecology 76:1067-1083

Walker MD, Walker DA, Welker JM, Arft AM, Bardsley T, Brooks PD, Fahnestock JT, Jones MH, Losleben M, Parsons AN, Seastedt TR, Turner PL (1999) Long-term experimental manipulation of winter snow regime and summer temperature in arctic and alpine tundra. Hydrol Process 13:2315-2330

Walsh NE, McCabe TR, Welker JM, Parsons AN (1997) Experimental manipulations of snow-depth: effects on 
nutrient content of caribou forage. Global Change Biol 3:158-164

Wielgolaski FE (2003) Climatic factors governing plant phenological phases along a Norwegian fjord. Int J Biometeorol 47:213-220

Wipf S, Rixen C, Mulder CPH (2006) Advanced snowmelt causes shift towards positive neighbour interactions in a subarctic tundra community. Global Change Biol 12:1496-1506

Wipf S, Stoeckli V, Bebi P (2009) Winter climate change in alpine tundra: plant responses to changes in snow depth and snowmelt timing. Clim Change 94:105-121 